\title{
Öğretmen Kılavuz Kitaplarının Kaldırılmasının Türkçe Öğretmenlerinin Görüişlerine Göre Değerlendirilmesi
}

\section{Evaluation of the Removal of Teachers' Guide Books According to the Opinions of Turkish Teachers}

\author{
Murat ATEŞ ${ }^{1}$ (@) Murat ACELE² ${ }^{2}$
}

${ }^{1}$ Murat Ateş (Doç. Dr.),

Necmettin Erbakan Üniversitesi, Ahmet Keleşoğlu Eğitim Fakültesi Türkçe Eğitimi Bölümü, Konya, Türkiye

E-posta: mates@erbakan.edu.tr

ORCID: 0000-0002-7361-6389

${ }^{2}$ Sorumlu yazar/Corresponding author: Murat Acele (Doktora Öğrencisi),

Necmettin Erbakan Üniversitesi, Eğitim Bilimleri

Enstitüsü, Konya, Türkiye

E-posta: murat.acele9@gmail.com

ORCID: 0000-0003-4760-5456

Başvuru/Submitted: 18.04.2021

Revizyon Talebi/Revision Requested:

01.09.2021

Son Revizyon/Last Revision Received:

13.09.2021

Kabul/Accepted: 14.09.2021

Online Yayın/Published Online: 10.12.2021

Atıf/Citation: Ates, Murat ve Acele, Murat. "Öğretmen Kılavuz Kitaplarının Kaldırılmasının Türkçe Öğretmenlerinin Görüşlerine Göre Değerlendirilmesi." Türkiyat Mecmuası-Journal of Turkology 31, 2 (2021): 533-553.

https://doi.org/10.26650/iuturkiyat.919503
Öz

Türkiye'de 2004 yılından itibaren hazırlanan öğretim programlarında, yapılandırmacı yaklaşım esas alınmış ve ders kitapları ile içerikleri de bu doğrultuda değişikliğe uğramıştır. Bu tarihten sonra hazırlanan programlardan biri de Türkçe Dersi Öğretim Programı'dır. Yeni programa göre Türkçe derslerinde kullanılacak kitaplar; ders kitabı, çalışma kitabı ve öğretmen kılavuz kitabı olarak hazırlanmıştır. Öğretmen kılavuz kitapları 2018-2019 eğitim öğretim yılından itibaren kullanımdan kaldırılmıştır. Bu çalışmanın amacı, öğretmen kılavuz kitaplarının kaldırılması konusunda Türkçe öğretmenlerinin görüşlerini belirlemektir. Araştırmada nitel veri toplama yöntemlerinden görüşme kullanıımış, uzman görüşleri doğrultusunda hazırlanan yarı yapılandırılmış görüşme formu ile elde edilen veriler içerik analizi yoluyla çözümlenmiştir. Elde edilen bulgular tablolar halinde sunulmuş ve yorumlanmıştır. Araştırmanın sonunda öğretmen kılavuz kitaplarının kaldırılmasının Türkçe dersini planlama, zaman yönetimi, işleniş bakımından olumsuz yönde etkilediği sonuçlarına ulaşılırken öğretmen yaratıcılığı bakımından olumlu etkilerinin olduğu, öğretmenin yaratıcılığını artırdığı sonuçlarına ulaşılmıştır. Ayrıca kılavuz kitaplar kaldırıldıktan sonra hazırlanan ders kitaplarının içerik açısından yetersiz olduğu, ders içi etkinliklerin sayısının azaldığı ve kılavuz kitapların kaldırılmasının öğrencilerin öğrenme süreçlerine herhangi bir etkisinin olmadığı sonuçlarına da ulaşılmıştır.

Anahtar kelimeler: Öğretmen Kılavuz Kitabı, Türkçe Eğitimi, Öğretmen Görüşü, Ders Kitabı, Görüşme

\section{ABSTRACT}

In the educational programs developed in Turkey since 2004, the constructivist approach was used and the textbooks and their content were changed in this direction. One of the programs prepared after this date is the Turkish Lesson Teaching Program. Books are to be used in Turkish lessons according to the new program; it has been prepared as a textbook, a workbook, and a teacher's guide. Teachers' guide books have been discontinued as of the 2018-2019 academic year. This study aims to determine the opinions of Turkish teachers about the abolition of teachers' guide books. In the research, inter views were used form qualitative data collection methods and data obtained using a semi-structured interview form prepared following expert opinions were analyzed through content analysis.The findings were presented and interpreted in tables. At the 
end of the study, it was found that removing the teachers' guide books was seen as having a negative impact on Turkish lessons in terms of planning, time management, and processing; although it has been concluded that it has positive effects on teachers' creativity. In addition, the results suggested that the textbooks prepared after the guide books were removed were insufficient, the number of in-course activities decreased, and the removal of the guide books did not affect the learning processes of the students.

Keywords: Teachers' Guide Books, Turkish Education, Teachers' Opinions, Textbook, Interview

\section{EXTENDED ABSTRACT}

Since 2004, in the field of education in Turkey has started to prepare a new curriculum. A constructivist approach was generally taken as a basis in the programs prepared, and course content, tools, and materials were rearranged according to this principle.The Turkish Primary Education Course curriculum based on the constructivist approach has been implemented for the Turkish course since 2005. According to the new curriculum, the books to be used in the course are prepared in three sets: as a textbook, a workbook, and the teachers' guide book. Teachers' guide books, which were prepared so that teachers would understand the new program more quickly,and to guide books them, started to be used for Turkish lessons.

This study aims to determine the opinions of Turkish teachers about the removal of teachers' guide books. To this end, the following sub-objectives were determined: 1-To establish teachers' views on how the removal of teachers' guide books affects planning Turkish lessons. 2- To establish teachers' views on how the abolition of teachers' guide books affects Turkish lessons in terms of time management. 3- To determine teachers' views on how the removal of teachers' guide books affectsTurkish lessons in terms of teaching. 4- To establish teachers' views on the effect of removing teachers' guide books on teachers'professional skills and creativity. 5- To establish teachers' opinions about the content and quality of the textbooks that came into use after the teachers'guide books had been removed. 6- To establish teachers' views on the number and quality of in-class activities after the removal of teacher' guide books. 7- To establish teachers' views on the effects of removing teachers' guide books on students' learning process.

In the research, qualitative data collection toolswere used, namely interviews. The study group for the enquiry consisted of 22 Turkish teachers who were selected through criterion sampling derived from purposeful sampling methods among Turkish teachers working in official secondary schools affiliated to the Ministry of National Education in Adana in the first semester of the 2019-2020 academic year.

While choosing the study group, it was taken into account that the teachers had worked both while using the guide book and after it had been removed. The data of the research were collected using a semi-structured interview form. After the questions to be included in the interview form had been prepared, they were presented for expert opinion, the necessary corrections were made in line with the opinions of the experts, and the interview form was finalized. The collected data were analyzed through content analysis. Accordingly, codes were created based on the data obtained. 
According to the sub-objectives determined in the study, the following findings have been reached: 10 of the 22 Turkish teachers interviewed for the first sub-objective believe that the removal of the guide books does not affect the planning of Turkish lessons. Five teachers interviewed stated that removing the guide books caused a waste of time for the teachers in terms of planning the lesson 11 of the teachers interviewed for the second sub-objective stated that the removal of the guide books had a negative effect on the course in terms of time management. However, 11 of them believed that there was no effect. According to the third sub-objective eight of the teachers stated that the guide books affected the lesson planning. Five of them stated that they were useful for guiding in terms of methods and techniques, and four of them said they saved time. Regarding the fourth sub-objective, eight of the teachers stated that removing the guide books increased the professional skills and creativity of the teachers, seven stated that the removal of the guide books did not have any effect on the teachers' professional skills and creativity. Six of the teachers stated that the guide books contributed positively to the professional skills and creativity of teachers who had just started in their profession. Nine teachers interviewed on the fifth sub-objective found the textbooks prepared after the removal of the guide books inadequate. Four teachers stated that nothing changed, and four teachers stated that the content of the book was simplified. Ten of the teachers interviewed for the sixth sub-objective stated that the number and quality of the activities in the textbooks decreased after the guide books were removed, while four teachers stated that the number and quality of the activities they performed in the lesson increased after the guide books were removed. While 17 teachers interviewed regarding the seventh sub-objective stated that removing the guide books did not affect the learning process of the students, five of them stated that this situation partially affected the process.

As a result, the following opinions were expressed the most according to each sub-objective in the interview with the participating teachers: The removal of the guide books has affected the planning of the Turkish course in various ways. Their removal has negatively affected the Turkish course in terms of time management. The guide books had ensured that teachers planned their lessons. The removal of guide books has increased the creativity of the teacher. After the guide books were removed, the content and competence of the textbooks decreased. After the guide books had been removed, the number of in-class activities decreased as did their quality. The removal of guide books did not affect students' learning processes, therefore, it would be appropriate to re-introduce teachers' guide books. 


\section{Giriş}

Eğitim anlayışları, eğitimin temel unsurlarından biri olan "bilgi”yi ele alış biçimleri bakımından farklılık gösterir. Geleneksel eğitim anlayışının esas aldığı pozitivist felsefeye göre bilgi nesneldir, bireyin dişında oluşur. Nesnel olan bilgi kitaplara yerleşmiştir ve bu bilginin öğrencilere öğretilmesi gerekmektedir. Bu anlayışa göre eğitim öğretmen merkezlidir. Öğretmen bilgiyi öğretendir. Buna karşılık olarak özellikle 20. yüzyılın ortalarından sonra gelişen eğitim anlayışına göre bilgi özneldir. Bu anlayış, geleneksel eğitim anlayışında yer alan bilginin keşfedilip ortaya çıkarıldığı düşüncesinin yerine bilginin kişi tarafından yorumlanıp yapılandırıldığını savunmaktadır. Bu anlayışa göre bilgi özneldir, kişiden izler taşır. Felsefedeki öznel gerçeklik üzerine kurulmuş bu yeni eğitim anlayışı yapılandırmacılık veya oluşturmacılık olarak adlandırılmaktadır. ${ }^{1}$

Türkiye'de 2004 yılından itibaren eğitim alanında yeni öğretim programları hazırlanmaya başlanmıştır. Hazırlanan programlarda genel olarak yapılandırmacı yaklaşım esas alınmış; ders içeriği, araç ve gereçleri bu esasa göre yeniden düzenlenmiştir.

Türkçe öğretiminde de yapılandırmacı yaklaşımın esas alındığı yeni bir eğitim programı hazırlanmıştır. ${ }^{2}$ Hazırlanan İlköğretim Türkçe Dersi Öğretim Programı 2005 yılından itibaren uygulanmaya başlamıştır. 2005 yılında yayımlanan programda, çoklu zekâ, beyin temelli öğrenme, öğrenci merkezli eğitim, bireysel farklılıklara duyarlı eğitim, sarmal, tematik ve beceri yaklaşımı gibi çeşitli eğitim yaklaşımlarından da yararlanıldığı belirtilmiştir. Ayrıca programda yapılandırıcı yaklaşıma göre öğrenme sürecinde öğrencinin ön bilgilerini harekete geçirme, gelişim düzeyini dikkate alma, etkili iletişim kurma, anlama, sorgulama, bilgiyi uygulama ve değerlendirme gibi kavramların önemli kavramlar olduğu vurgulanmıştır. Öğrenci merkezli öğrenmeyi temel alan yapılandırıcı yaklaşımın, öğrenme sürecinde öğrenci katılımına, iş birlikli öğrenmeye ve öğretmen rehberliğine ağırlık verdiği belirtilmiştir. ${ }^{3}$

2006 yılında yayımlanan İlköğretim Türkçe Dersi (6, 7, 8. sınıflar) Öğretim programında benimsenen yaklaşımla ilgili olarak şu ifadeler yer almaktadır:

Öğrenme sürecinde öğrencinin birikim ve deneyimlerinden hareketle sorunlara çözümler üretmesini, öğrenme- öğretme etkinliklerinde öğrencinin gelişim düzeyinin dikkate alınmasını, dolayısıyla değerlendirmede öğretim sürecindeki gelişimin de önemli olduğu benimsenmiştir. Bu yaklaşımın temel hedefi, öğrencinin öğretmen rehberliğinde; etkili iletişim kurması, grup çalışmalarına katılması, öğrendiklerini aşamalı bir biçimde inşa etmesidir. ${ }^{4}$

Hazırlanan bu yeni programlar derste kullanılacak ders kitaplarında da değişiklik yapılmasını zorunlu kılmıştır. Yeni programa göre Türkçe dersinde kullanılacak kitaplar "Ders Kitabı", “Çalışma Kitabı” ve “Öğretmen Kılavuz Kitabı” olmak üzere üçlü set halinde hazırlanmıştır.

\footnotetext{
Yüksel Özden. Öğrenme ve Öğretme. (Ankara: Pegem Akademi 2021), 54.

Firdevs Güneş. Türkçe Öğretimi Yaklaşımlar ve Modeller, (Ankara: Pegem Akademi), 2020.

MEB. Talim ve Terbiye Kurulu Başkanlığı İlköğretim Türkçe Dersi(1-5. Sınıflar) Öğretim Programı ve Kılavuzu. Ankara: MEB Basimevi. (2005).

4 MEB. Talim ve Terbiye Kurulu Başkanlığı İlköğretim Türkçe Dersi(6,7,8. Sınıflar) Öğretim Programı ve Kılavuzu: MEB Basımevi. (2006).
} 
Yeni programın, eğitimin uygulayıcısı olan öğretmenler tarafından daha çabuk anlaşılması ve öğretmenlere rehberlik etmesi amacıyla hazırlanan öğretmen kılavuz kitapları Türkçe dersi için de kullanılmaya başlanmıştır. Hazırlanan bu yeni programlara göre öğretmenin rolü de değişmiştir. Buna göre öğretmen, öğrenci için öğrenme sürecinde bir rehberdir. Değişen programı uygulamada öğretmene rehberlik edecek eğitim aracı ise öğretmen kılavuz kitaplarıdır.

Öğretmen kılavuz kitaplarında bulunması gereken özellikler 12 Eylül 2012 tarihinde yayınlanan Millî Ĕgitim Bakanlı̆̆l Ders Kitapları ve Ĕgitim Araçları Yönetmeliği’nin “Öğretmen kılavuz kitabının hazırlanması" başlıklı 10. Maddesine göre şu şekilde belirtilmiştir:

"(1) Öğretmen kılavuz kitabında;

a) Konuların işlenişinde ulaşılmak istenen kazanımlar/hedefler belirtilir.

b) Eğitim ve öğretim programlarında yer alan kazanım/amaç ve açıklamalar doğrultusunda öğrencilere bilgi, beceri, tutum ve davranışların kazandırılmasında öğretmene yardımcı olacak ve öğretmeyi kolaylaştıracak bilgi, örnek ve uygulamalara yer verilir.

c) Bilgi, beceri, tutum ve davranışlar ile değerlerin öğrencilere kazandırılmasında kullanılabilecek araç-gereçle birlikte öğretim yöntem ve teknikleri ile ayrıca;

1) Konu ile ilgili zaman analizine ve konunun işleniş planına,

2) Öğretmenin konu ile ilgili yapacağı ön hazırlıklara,

3) Konuya girerken daha önce işlenen konularla ilişkisini sağlayacak ve öğrencinin ilgisini çekecek hatırlatmalara, sorulara ve benzeri unsurlara,

4) Ders kitabında yer alan ve açıklama gerektiren şekil, şema, çizelge ve benzeri yardımcı unsurlara, yer verilir.

ç) Öğrencileri araştırmaya, günlük yaşamda karşılaşılan çeşitli sorunlara çözüm üretmeye yöneltecek ödev, proje ve benzeri örnek çalışmalara yer verilir.

d) Konuların sonunda, gerekli görülmesi halinde verilen kavramlarla ilgili sözlük bulunur.” 5

5 “Millî Ĕgitim Bakanlı̆̆ Ders Kitapları ve Eğitim Araçları Yönetmeliği”’ Resmi Gazete, 12 Eylül 2012 Sayı:28409 Erişim:18 Aralık 2019 www.resmigazete.gov.tr 
Kılavuz kitapların kullanılmaya başlanmasından sonra bu kitapların içeriği, etkililiği ve benzeri yönleri birçok araştırmacı [Erdoğan (2007), Kulantaş (2007), Durukan (2008), Şahin (2008),.Kılıç (2009),Ayvacı ve Er-nas (2009), Ayvacı ve Şenel Çoruhlu (2011) Göçer (2011), İlik (2011), Sert (2012), Şeker (2014), Yaylı ve Solak (2014), Göçer ve Aktürk (2015),Küçükaydın ve İşcan (2017)] ${ }^{6}$ için birer araştırma konusu olmuştur.

\section{Amaç}

$\mathrm{Bu}$ araştırmanın amacı öğretmen kılavuz kitaplarının kaldırılması konusunda Türkçe öğretmenlerinin görüşlerinin neler olduğunu belirlemektir. Bu amaca dayanarak araştırmanın alt amaçları şu şekilde oluşturulmuştur:

1. Öğretmen kılavuz kitaplarının kaldırılmasının Türkçe dersini planlama açısından nasıl etkilediği ile ilgili öğretmen görüşlerini belirlemek

6 Tolga Erdoğan. "İlköğretim 3. Sınıf Türkçe Dersi Öğretmen Kılavuz Kitabı Ve Öğrenci Çalışma Kitabının Yapılandırmacı Yaklaşıma Uygunluğu.” Mehmet Akif Ersoy Üniversitesi Eğitim Fakültesi Dergisi 8.14 (2007), 163-172.

Nazike Kulantaș. "4. ve 5. Sinıf Sosyal Bilgiler Dersinde Kullanılan Ders ve Öğrenci Çalıșma Kitapları ile Öğretmen Kılavuz Kitaplarının Öğretmen, Öğrenci ve Veli görüslerine Göre Değerlendirilmesi.” (Doktora tezi, Gazi Üniversitesi Eğitim Bilimleri Enstitüsü, 2007).

Erhan Durukan. "Türkçe Dersiöğretim Programının (6-8. Sinıflar) Hedef ve Kazanımları Doğrultusunda 7. Sinıf Türkçe Dersiöğrenci Çalışma ve Öğretmen Kılavuz Kitaplarının Değerlendirilmesi”(Yüksek lisans tezi, Karadeniz Teknik Üniversitesi, 2008).

Ayfer Şahin. "İlköğretim Birinci Sınıf Türkçe Ders Kitabı, Öğrenci Çalışma Kitabı Ve Öğretmen Kılavuz Kitabının Öğretmen Görüşlerine Dayalı Olarak Değerlendirilmesi." Ahi Evran Üniversitesi Kırşehir Eğitim Fakültesi Dergisi 9.3 (2008), 133-146.

Abdurrahman Kılıç. "İlköğretim Birinci Kademe Derslerinde Öğretmen Kılavuzuna Duyulan İhtiyaç Ve İçeriği.” Selçuk Üniversitesi Sosyal Bilimler Enstitüsü Dergisi 21 (2009), 295-309.

Hakan Şevki Ayvacı ve Sibel Er-Nas,. "Öğretmen Kılavuz Kitaplarının Yapılandırmacı Kurama Göre Öğretmen Görüşlerine Dayalı Olarak Değerlendirilmesi”, Necatibey Eğitim Fakültesi Elektronik Fen ve Matematik Ĕgitim Dergisi, Cilt 3, Say1 2 (2009), 212-225.

Hakan Şevki Ayvacı. Tülay Şenel Çoruhlu. «Illköğretim 7. Sınıf Fen Ve Teknoloji Öğretmen Kılavuz Kitabının Öğretmen Görüşlerine Dayalı Olarak Değerlendirilmesi.» Erzincan Üniversitesi Eğitim Fakültesi Dergisi 13.1 (2011), 24-38.

Ali Göçer. “İlköğretim İkinci Kademe Türkçe Öğretmen Kılavuz Kitaplarının İ̧slevselliğinin Belirlenmesi”, Journal of International Social Research, 4/16, (2011): 154-164.

Mustafa İlik. "İlköğretim 8. Sinıf Türkçe Dersi Öğretmen Kılavuz Kitabının Yapılandırmacı Öğrenme Anlaylşına Göre Inncelenmesi” (Yüksek Lisans tezi, Frrat Üniversitesi Sosyal Bilimler Enstitüsü, 2011).

Fethiye Sert. "İlköğretim 7. Sınıf Türkçe Dersi Öğretmen Kılavuz Kitabının Yapılandırmacı Öğrenme Anlayışına Göre İncelenmesi”. (Yüksek Lisans tezi, Frrat Üniversitesi, 2012).

Mustafa Şeker. "Sosyal Bilgiler Ders, Çalışma ve Öğretmen Kılavuz Kitaplarının Öğrenme Stilleri Açısından İncelenmesi”. Kastamonu Eğitim Dergisi 22 (2014) :41-56.

Derya Yaylı ve Murat Solak. "Ortaokul Türkçe Ders Kitaplarında ve Öğretmen Kılavuz Kitaplarında Yer Alan Yazma Etkinliklerine Dair Öğretmen Görüşleri”. Electronic Turkish Studies, 9/6 (2014): 1139-1151.

Ali Göçer ve Yunus Aktürk. "İlk ve ortaokul öğretmenlerinin öğretmen kılavuz kitabına yönelik algıları: Metafor analizi”, Uluslararast Türk Eğitim Bilimleri Dergisi, 4, (2015): 186-199.

Menşure Alkış Küçükaydın ve Adem İşcan. «Illköğretim 3. Sınıf Türkçe Ders Kitapları ve Öğretmen Kılavuz Kitabının Yapılandırmacı Öğrenme Yaklaşımına Uygunluk Düzeyi.» Ana Dili Eğitimi Dergisi 5/1 (2017), 1-13. 
2. Öğretmen kılavuz kitaplarının kaldırılmasının Türkçe dersini zaman yönetimi açısından nasıl etkilediği ile ilgili öğretmen görüşlerini belirlemek

3. Öğretmen kılavuz kitaplarının kaldırılmasının Türkçe dersini işleniş yönünden nasıl etkilediği ile ilgili öğretmen görüşlerini belirlemek

4. Öğretmen kılavuz kitaplarının kaldırılmasının öğretmenlerin meslekî becerisi ve yaratıcılığına etkisi ile ilgili öğretmen görüşlerini belirlemek

5. Öğretmen kılavuz kitaplarının kaldırılmasından sonra kullanılmaya başlanan ders kitaplarının içerik ve niteliği ile ilgili öğretmen görüşlerini belirlemek

6. Öğretmen kılavuz kitaplarının kaldırılmasından sonra ders içi etkinliklerin sayısına ve niteliğine yönelik öğretmen görüşlerini belirlemek

7. Öğretmen kılavuz kitaplarının kaldırılmasının öğrencilerin öğrenme süreci açısından etkileri ile ilgili öğretmen görüşlerini belirlemek

\section{Yöntem}

Çalışma, öğretmen kılavuz kitaplarının kaldırılması konusunda Türkçe öğretmenlerinin görüşlerinin değerlendirilmesi amacına dayanan nitel bir araştırmadır. "Nitel araştırma, gözlem, görüşme ve doküman analizi gibi nitel veri toplama yöntemlerinin kullanıldığı, algıların ve olayların doğal ortamda, gerçekçi ve bütüncül bir biçimde ortaya konmasına yönelik nitel bir sürecin izlendiği araştırmadır". ${ }^{7}$ Araştırmada nitel veri toplama araçlarından görüşmeden yararlanılmıştır. Stewart ve Cash'e göre görüşme, önceden belirlenmiş ve ciddi bir amaç için yapılan, soru sorma ve yanıtlama tarzına dayalı karşılıklı ve etkileşimli bir iletişim sürecidir. ${ }^{8}$

\section{Çalışma Grubu}

Araştırmanın çalışma grubunu 2019-2020 eğitim öğretim yılının 1. döneminde Adana ilinde Millî Eğitim Bakanlığına bağlı resmî ortaokullarda görev yapan Türkçe öğretmenleri arasından amaçlı örnekleme yöntemlerinden ölçüt örneklemesi yoluyla seçilmiş 22 Türkçe öğretmeni oluşturmaktadır. Çalışma grubu seçilirken öğretmenlerin hem kılavuz kitap kullanılırken hem de kaldırıldıktan sonra görev yapmış olmaları dikkate alınmıştır.

Çalışma grubunun cinsiyet dağılımı Tablo 1'de verilmiştir.

7 Ali Yıldırım ve Hasan Şimşek. Sosyal Bilimlerde Nitel Araştırma Yöntemleri (5. Baskı).(Ankara: Seçkin Yayıncilik, 2005), 39.

8 Yıldırım ve Şimşek. Sosyal Bilimlerde Nitel Araştırma Yöntemleri, 119. 
Tablo 1. Çalışma grubunun cinsiyet dağılımı

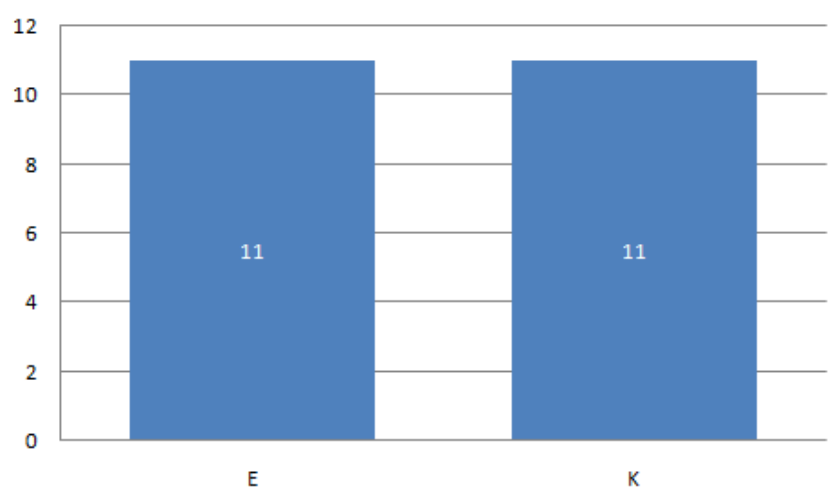

Tablo 1'de görüldüğg̈ gibi çalışma grubu 11 erkek 11 bayan öğretmenden oluşmaktadır. Çalışma grubunun meslekî kıdemleri Tablo 2'de gösterilmiştir.

Tablo 2. Çalışma grubunun meslekî kıdemlerine göre dağılımı

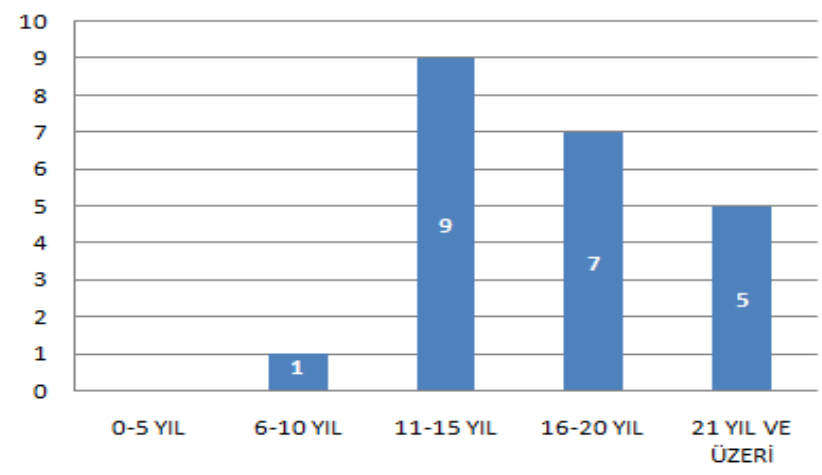

Tablo 2'ye göre çalışma grubunda yer alan 22 öğretmenden 1'i 6-10 yıl arası, 9'u 11-15 yıl arası, 7'si 16-20 yıl arası, 5'i de 21 yıl ve üzeri çalışma kıdemine sahiptir.

Çalışma grubunun mezun olduğu bölüm ve fakültelere göre dağılımı Tablo 3 ’te verilmiştir. 
Tablo 3. Çalışma grubunun mezun olunan bölümlere göre dağglımı

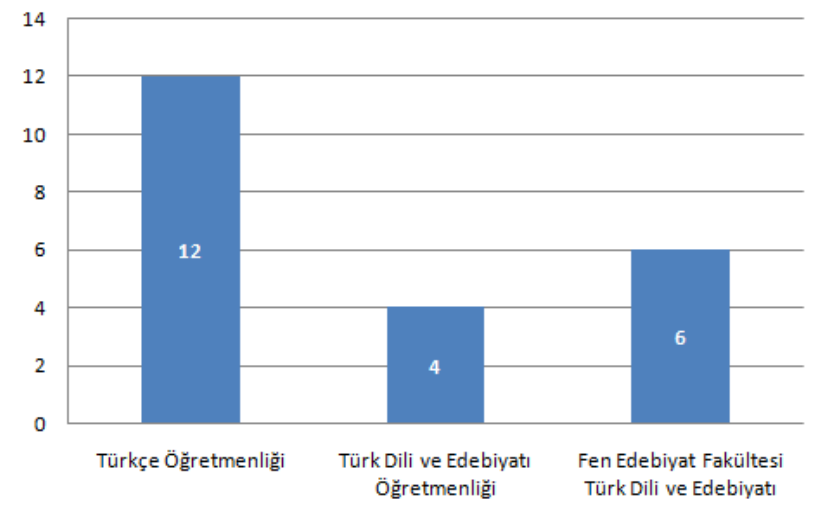

Tablo 3'e göre çalışma grubunda yer alan 22 öğretmenin 12'si Türkçe Öğretmenliği, 4'ü Türk Dili ve Edebiyatı Öğretmenliği, 6'sı ise Fen Edebiyat Fakültesi Türk Dili ve Edebiyatı bölümlerinden mezun olmuşlardır.

\section{Verilerin Toplanması ve Analizi}

Çalışmanın verileri, araştırmacılar tarafından hazırlanmış yarı yapılandırılmış görüşme formu ile elde edilmiştir. Görüşme formu hazırlanırken 3 öğretmen ve 2 akademisyen olmak üzere 5 uzman görüşü alınmış, görüşme formunda yer alan sorular bu görüşlere göre düzenlenmiştir. Görüşme formu ile elde edilen veriler araştırmacılar tarafından bilgisayar ortamına aktarılmıştır. Toplanan veriler içerik analizi yoluyla çözümlenmiştir. Sorulara verilen cevaplar araştırmacılar tarafından okunmuş, cevapların niteliğine göre veriler kodlanmıştır. Kodlama yapılırken verilerden çıkarılan kavramlara göre yapılan kodlama kullanılmıştır. Bu tür araştırmalarda araştırmacı verileri satır satır okur ve araştırmanın amacı çerçevesinde önemli olan boyutları saptamaya çalışır. Ortaya çıkan anlama göre araştırmacı ya kendisi kodlar üretir ya da doğrudan verilerden yola çıkarak kodlar oluşturur. ${ }^{9}$ Kodlama yapılırken tutarlılığı sağlamak için kodlar bir alan uzmanı ve araştırmacı tarafından ayrı ayrı oluşturulmuş, Huberman ve Miles ${ }^{10}$ tarafından geliştirilen formül kullanılarak güvenirlik çalışması yapılmıştır. (Güvenirlik = Görüş Birliği / (Görüş Birliği + Görüş Ayrılığg1). Formülün 2. kez uygulanmasından sonra güvenirlik yüzdesi \% 89 çıkmıştır. Bu değer ile çalışmada yapılan kodlamanın güvenirliğinin sağlandığı kabul edilmiştir. Sonrasında kodlar temalarla ilişkilendirilerek veriler kodlara ve temalara göre düzenlenmiştir. Veriler raporlaştırılırken her bir katılımcı "Ö” harfi ve numara verilerek kodlanmıştır (Ö1,Ö2, Ö3...). Raporlaştırma sürecinde katılımcıların görüşlerinden doğrudan alıntı yapılırken bu kodlar kullanılmıştır.

9 Yıldırım ve Şimşek. Sosyal Bilimlerde Nitel Araştırma Yöntemleri, 232.

10 Matthew B. Miles ve A. Michael Huberman, Genişletilmiş bir kaynak kitap: Nitel veri analizi,(3.Bask1). (Ankara:Pegem Akademi,2019),64. 


\section{Bulgular}

Çalışmanın 1. alt amacı olan öğretmen kılavuz kitaplarının kaldırılmasının Türkçe dersini planlama açısından nasıl etkilediği ile ilgili öğretmen görüşleri Tablo 4’te verilmiştir.

Tablo 4. Türkçe dersini planlama açısından nasıl etkilediği ile ilgili öğretmen görüşleri

\begin{tabular}{|c|c|c|c|}
\hline Kodlar & f & $\%$ & Örnek Cümle \\
\hline Etkilemedi & 10 & $45,45 \%$ & $\begin{array}{l}\text { Meslekî birikimlerim ve deneyimlerin } \\
\text { doğrultusunda herhangi bir güçlük } \\
\text { yaşamadım (Ö8) }\end{array}$ \\
\hline Zaman kaybına neden oldu & 5 & $22,73 \%$ & $\begin{array}{l}\text { Internetten hazır planlar aramaya } \\
\text { yöneltti. Planlama üzerinde fazladan } \\
\text { çalışmaya neden oldu. Ayrı ayrı } \\
\text { ölçekler hazırlamak zorunda } \\
\text { kalıyorum. Tüm bunlar zamanımdan } \\
\text { çalıyor.(Ö19) }\end{array}$ \\
\hline Uygulamada birlikteliği bozdu & 3 & $13,64 \%$ & $\begin{array}{l}\text { Her ögretmen kendine göre planlama } \\
\text { yaptı. Bu da sınıflar arası dersin } \\
\text { işlenişi konusunda farlılıklara sebep } \\
\text { oldu (Ö18) } \\
\text { Planlamayı ögretmene bıraktı belli } \\
\text { ölçüde. Bu da karmaşaya neden oluyor. } \\
(\ddot{1} 1)\end{array}$ \\
\hline $\begin{array}{l}\text { Sınıfın düzeyine göre farklı etkinlikler } \\
\text { planlıyorum }\end{array}$ & 3 & $13,64 \%$ & $\begin{array}{l}\text { Kılavuz kitaplarda ögretmenin hangi } \\
\text { saat ne yapacă̆ı planlanmıştı. Ancak } \\
\text { bu planlama bazı çevrelerde bazı } \\
\text { sinıflarda uygun olmuyordu. Kılavuz } \\
\text { kitap kaldırılınca öğretmenlerimiz sınıf } \\
\text { ihtiyacına göre planlamayı kendileri } \\
\text { yapabiliyor. (Ö6) }\end{array}$ \\
\hline Neler yaptığımızı takip zorlaştı & 1 & $4,55 \%$ & $\begin{array}{l}\text { Neler yapacă̆ımızı biliyoruz ama } \\
\text { ögrencilerin davranışlarını düzeltirken } \\
\text { dalma olabiliyor. Kılavuz kitabın } \\
\text { varlı̆̆ı neler yaptığımızı kontrol } \\
\text { yönünden yardımcı oluyordu. (Ö14) }\end{array}$ \\
\hline Toplam & 22 & $100,00 \%$ & \\
\hline
\end{tabular}

Tablo 4'e göre görüşme yapılan 22 Türkçe öğretmeninden 10'u kılavuz kitapların kaldırılmasının Türkçe dersini planlama açısından etkilemediği görüşündedir. Görüşme yapılan 5 öğretmen kılavuz kitapların kaldırılmasının dersi planlama açısından öğretmenlere zaman kaybına yol açtı̆̆ yönünde görüş belirtmiştir. 3'ü kılavuz kitapların kaldırılmasının uygulamada birliği bozduğunu belirtirken, 3 ’ü de her sinıf düzeyine uygun plan yapabildiği için bu durumun kendisine esneklik sağladığını belirtmiş̧tir.

Çalışmanın 2. alt amacı olan öğretmenlerin kılavuz kitapların kaldırılmasının zaman yönetimi açısından dersi nasıl etkilediğine dair görüşleri Tablo 5'te verilmiştir. 
Tablo 5. Öğretmenlerin kılavuz kitapların kaldırılmasının zaman yönetimi açısından dersi nasıl etkilediğine dair görüşleri

\begin{tabular}{|c|c|c|c|}
\hline Kodlar & f & $\%$ & Örnek Cümle \\
\hline Olumsuz etkiledi & 11 & $50 \%$ & $\begin{array}{l}\text { Zaman yönetimi açısından olumsuz } \\
\text { etkilemiştir. (Ö4) } \\
\text { Zaman yönetimi açısından öğretmenin } \\
\text { aleyhine oldu.(Ö15) } \\
\text { Olumsuz etkiledi. Kendi planlamamı yaparken } \\
\text { bazı etkinliklere gerektiğinden az veya çok } \\
\text { zaman ayırabiliyorum.(19) } \\
\text { Kllavuz kitaplarda zaman yönetimini daha } \\
\text { verimli değerlendiriyorduk. Sadece kılavuz } \\
\text { kitaba da bağll kalmıyorduk. Alternatif } \\
\text { etkinliklere de yer veriyorduk. Zaman dolu } \\
\text { dolu geçiyordu. Bizim iş yoğunluğumuzu } \\
\text { azaltıyordu. (Ö17) } \\
\text { Bazen süreyi yetiştirme konusunda sıkıntı } \\
\text { yaşıyorum. Süreyi kılavuzla daha iyi } \\
\text { ayarlayabiliyordum. (Ö21) } \\
\text { Kılavuz kitabı daha sistemli ve düzenli } \\
\text { olmamızı sağllyordu.(Ö22) }\end{array}$ \\
\hline Hissedilir bir etkisi olmadı & 11 & $50 \%$ & $\begin{array}{l}\text { Çok etkilemedi(Ö11) } \\
\text { Fazla etkisi yok (Ö13) } \\
\text { Yıllık ve günlük planlar hazırlayıp plan } \\
\text { doğrultusunda dersi işlediğimizde zaten } \\
\text { zaman yönetimini de sağlamış oluyoruz. } \\
\text { Kılavuz kitabın olmaması çok da bir eksiklik } \\
\text { hissettirmedi. (Ö5) } \\
\text { Bu konuda herhangi bir sorun yaşamadım. } \\
\text { (Ö8) } \\
\text { Farkında bile değilim(Ö9) }\end{array}$ \\
\hline Toplam & 22 & $100,00 \%$ & \\
\hline
\end{tabular}

Tablo 5'e göre görüşme yapılan öğretmenlerin 11'i kılavuz kitapların kaldırılmasının zaman yönetimi açısından dersi olumsuz etkilediği görüşünü belirtirken, 11 ' $\mathrm{i}$ ise herhangi bir etkisinin bulunmadığ1 görüşündedir. Olumsuz etkilediği görüşünde olan öğretmenlerden bazıları ders içinde yer alan her bir etkinliğe ne kadar süre ayırması konusunda sorun yaşadığını dile getirirken bazısı etkinlikleri planlarken fazla zaman ayırmak zorunda kaldığını belirtmiştir. Kılavuz kitapların kaldırılmasının zaman yönetimi açısından dersi etkilemediğini düşünen öğretmenler ise yıllık ve günlük planlara göre hareket ettiklerini, zamanı bu şekilde planladıklarını belirtmişlerdir.

Çalışmanın 3. alt amacı olan öğretmen kılavuz kitaplarının kaldırılmasının Türkçe dersini işleniş yönünden nasıl etkilediği ile ilgili öğretmen görüşleri Tablo 6'da verilmiştir. 
Tablo 6. Öğretmen kılavuz kitaplarının kaldırılmasının Türkçe dersini işleniş yönünden nasıl etkilediği ile ilgili öğretmen görüşleri

\begin{tabular}{|c|c|c|c|}
\hline Kodlar & f & $\%$ & Örnek Cümle \\
\hline Planlı olmayı sağlıyordu & 8 & $36,36 \%$ & $\begin{array}{l}\text { Dersin işlenişini bir program dahilinde } \\
\text { yapmamızı sağlıyordu...(Ö4) } \\
\text { Derse hazırlıksız geldiğin anlarda bile ne } \\
\text { yapacağımı biliyordum.(Ö5) }\end{array}$ \\
\hline Yöntem ve teknik açısından yol göstericiydi & 5 & $22,73 \%$ & $\begin{array}{l}\text { Derste kullanmam gereken yöntem ve teknikler } \\
\text { hakkında kolaylıklar sağlıyordu.(Ö22) } \\
\text { Dersin nasıl işleneceği ve farklı etkinliklerin } \\
\text { yer alması açısından kolaylık sağllyordu. }\end{array}$ \\
\hline Zaman tasarrufu sağlıyordu & 4 & 18,18 & $\begin{array}{l}\text { Zamanı daha verimli kullanmamızı } \\
\text { sağlıyordu...(Ö17) } \\
\text {...Zaman tasarrufu sağlıyordu...(Ö19) }\end{array}$ \\
\hline Başvuru kaynağıydı & 3 & $13,64 \%$ & $\begin{array}{l}\text { Bazı konularda akademik tartışmalar hala } \\
\text { sürüyor. Ortaokul düzeyinde neyi ne kadar } \\
\text { anlatmamız gerektiğinde başvuracağımız bir } \\
\text { kaynaktı(Ö21) } \\
\text { Tartışma yaratacak konularda Hadi kılavuz } \\
\text { kitaba bakalım, diyordum(Ö16) }\end{array}$ \\
\hline Etkinlikler açısından doyurucuydu & 2 & $9,09 \%$ & $\begin{array}{l}\text { Etkinlik, performans ve proje ödevlerinin } \\
\text { içeriği ve değerlendirme formları oldukça } \\
\text { doyurucuydu.(Ö8) } \\
\text { Farklı etkinlik,farklı soru ve çallşmalarla örnek } \\
\text { oluyordu.(Ö12) }\end{array}$ \\
\hline Toplam & 22 & $100,00 \%$ & \\
\hline
\end{tabular}

Tablo 6 incelendiğinde görüşme yapılan öğretmenlerden 8'i kılavuz kitapların planlı olmayı sağladığı yönünde görüş belirtirken 5'i yöntem ve teknik açısından yol gösterici olduğu, 4’ü zaman tasarrufu sağladığı konusunda görüş belirtmiştir. Planlı olmayı sağladığı görüşünde olan öğretmenler genel olarak kılavuz kitaplar sayesinde derste nerede, ne zaman, ne yapmaları gerektiğini bildiklerini ve bunun dersin işlenişini daha planlı hale getirdiğini ifade etmişlerdir. Yöntem ve teknik konusunda kolaylık sağladığı görüşünde olanlar ise kılavuz kitabın derste kullanacağı öğretim yöntem ve teknikleri konusunda yönlendirici olduğu görüşünü belirtmişlerdir. Ayrıca görüşme yapılan öğretmenlerden 3 'ü kılavuz kitapları tartışmalı konularda başvurulacak bir kaynak olarak görmektedir.

Çalışmanın 4. alt amacı olan kılavuz kitapların kaldırılmasının öğretmenin meslekî becerisi ve yaratıcılığına etkisi konusundaki öğretmen görüşleri Tablo 7'de verilmiştir. 
Tablo 7. Kılavuz kitapların kaldırılmasının öğretmenin meslekî becerisi ve yaratııılığına etkisi konusundaki öğretmen görüşleri

\begin{tabular}{|c|c|c|c|}
\hline Kodlar & f & $\%$ & Örnek Cümle \\
\hline Kaldırılması yaratıcılığı arttırdı & 8 & $36,36 \%$ & $\begin{array}{l}\text { Ben yaratıcılı̆̆ın arttı̆̆ını ve dolayısıyla } \\
\text { ögretmenin meslekî becerisinin geliş̧tiğini } \\
\text { düsünüyorum. (Ö5) } \\
\text { Yaratıcılığın artacağını düşünüyorum. } \\
\text { Öğretmen farklı sınıf düzeylerine göre kendini } \\
\text { hazırlayacaktır.(Ö2) }\end{array}$ \\
\hline Etkisi yoktu & 7 & $31,82 \%$ & $\begin{array}{l}\text { Öğretmenin meslekî becerisine ve } \\
\text { yaratıcılı̆̆ına herhangi bir etkisi yoktu.(Ö10) } \\
\text { Meslekî beceri ve yaratıcılığl çok etkilediğini } \\
\text { düşünmüyorum.(Ö18) }\end{array}$ \\
\hline $\begin{array}{l}\text { Göreve yeni başlayanlar için } \\
\text { yararlıydı }\end{array}$ & 6 & $27,27 \%$ & $\begin{array}{l}\text { Yeni mezun öğretmen arkadaşlar için iyi bir } \\
\text { yol göstericiydi. Mesleğinin ilk yıllarında } \\
\text { olanlar için kılavuz kitapların kaldırllması bu } \\
\text { açıdan olumsuz olmuştur.(Ö22) } \\
\text { Meslekte tecrübesi olan öğretmenleri fazla } \\
\text { etkilememiş olabilir ama mesleğe yeni } \\
\text { başlamış Türkçe öğretmenleri için KK'nin } \\
\text { zorunlu olduğunu düşünüyorum.(Ö21) }\end{array}$ \\
\hline $\begin{array}{l}\text { Meslekî becerinin gelişmesine } \\
\text { katkı sağlıyordu }\end{array}$ & 1 & $4,55 \%$ & $\begin{array}{l}\text { Öğretmen, KK mevcutken kılavuz kitaba } \\
\text { meslekî becerisini de katarak daha etkindi } \\
\text { ancak şimdi sadece meslekî becerisi ile bu işi } \\
\text { yürütüyor.(Ö4) }\end{array}$ \\
\hline Toplam & 22 & $100,00 \%$ & \\
\hline
\end{tabular}

Tablo 7 incelendiğinde görüşme yapılan öğretmenlerden 8'i kılavuz kitapların kaldırılmasının öğretmenlerin meslekî beceri ve yaratıcılıklarını arttırdığ görüşünü belirtmiştir. Bu görüşte olan öğretmenler genellikle öğretmenlerin kılavuz kitabın yokluğunda farklı sınıf düzeylerinde farklı yöntem ve tekniklerle ders işlemesi gerektiğini, bunun da öğretmenin yaratıcılığını olumlu şekilde etkilediği yönünde görüş belirtmiştir. Yine görüşme yapılan öğretmenlerden 7'si kılavuz kitapların kaldırılmasının öğretmenin meslekî beceri ve yaratıcılığına herhangi bir etkisinin olmadığı yönünde görüş belirtmiştir. Öğretmenlerden 6'sı kılavuz kitapların mesleğe yeni başlayan öğretmenlerin meslekî beceri ve yaratıcılıklarına olumlu katkısı olduğu yönünde görüş belirtmiştir. Görüşme yapılan öğretmelerden biri de kılavuz kitabın meslekî beceriye ve yaratıcılığa katkı sağladığını, kaldırılmasının bu açıdan olumsuz olduğunu belirtmiştir.

Çalışmanın 5. alt amacı olan kılavuz kitaplar kaldırıldıktan sonra basılan ders kitaplarının içerik ve yeterliliği hakkındaki öğretmen görüşleri Tablo 8'de verilmiştir. 
Tablo 8. Kılavuz kitaplar kaldırıldıktan sonra basılan ders kitaplarının içerik ve yeterliliği hakkındaki öğretmen görüşleri

\begin{tabular}{|c|c|c|c|}
\hline Kodlar & f & $\%$ & Örnek Cümle \\
\hline Yetersiz buluyorum & 9 & $40,91 \%$ & $\begin{array}{l}\text { Öncesinde de sonrasında da istediğimiz } \\
\text { düzeyde ve sayıda etkinlik yok. Öğrencileri } \\
\text { sınava hazırlayacak içeriğe de sahip } \\
\text { değiller. (Ö3) } \\
\text { Ders kitaplarında özellikle dilbilgisi } \\
\text { konusunda eksiklikler çok. Bu anlamda } \\
\text { içerikler yetersiz.(Ö7) }\end{array}$ \\
\hline Değişmedi & 4 & $18,18 \%$ & $\begin{array}{l}\text { Değişen bir şey yok.(Ö14) } \\
\text { Ders kitabının içeriği ve yeterliliği } \\
\text { değişmedi.(Ö15) }\end{array}$ \\
\hline İçerik sadeleştirildi & 4 & $18,18 \%$ & $\begin{array}{l}\text { Içeriğin sadeleştirildiğini düşünüyorum. } \\
\text { etkinlikler azaltıldı.(Ö1) } \\
\text { Kılavuz kitaplar kaldırıldıktan sonra içerik } \\
\text { biraz daha daralmıştır.(Ö17) }\end{array}$ \\
\hline Metinler sınıf seviyesine uygun değil & 3 & $13,64 \%$ & $\begin{array}{l}\text { Son yıllarda ders kitaplarının içi boşaltıldl. } \\
\text { İçerik çocuğun seviyesinin çok altında. } \\
\text { Öğrenciler yapmak istemiyor.(Ö16) } \\
\text { Bazı metinler sınıf seviyesinin üstünde } \\
\text { veya altında olabiliyor. Bu metinlerde } \\
\text { çocukların yorum yapma istek ve yeteneği } \\
\text { düşük oluyor.(Ö6) }\end{array}$ \\
\hline Yeterli buluyorum & 2 & $9,09 \%$ & $\begin{array}{l}\text { Ders kitapları yeterli ancak } \\
\text { zenginleştirilirse daha faydalı olur.(Ö13) } \\
\text { Çok memnunum sorun yok sadece sürede } \\
\text { sıkıntı yaşıyorum(Ö9) }\end{array}$ \\
\hline Toplam & 22 & $100,00 \%$ & \\
\hline
\end{tabular}

Tablo 8 incelendiğinde görüşme yapılan 9 öğretmen kılavuz kitapların kaldırılmasından sonra okutulan ders kitaplarını yetersiz bulmaktadır. 4 öğretmen herhangi bir şeyin değişmediği, 4 öğretmen de kitap içeriklerinin sadeleştirildiği yönünde görüş belirtirken 3 öğretmen ders kitabında yer alan metinlerin sınıf seviyesine uygun olmadığını söylemiştir. Ayrıca 2 öğretmen ders kitaplarını içerik ve yeterlilik bakımından olumlu bulduğunu ifade etmiştir.

Çalışmanın 6. alt amacı olan öğretmen kılavuz kitaplarının kaldırılmasından sonra ders içi etkinliklerin sayısı ve niteliğine yönelik öğretmen görüşleri Tablo 9'da verilmiştir. 
Tablo 9. Öğretmen kılavuz kitaplarının kaldırılmasının ders içi etkinliklerin sayısı ve niteliğine etkisine yönelik öğretmen görüşleri

\begin{tabular}{|c|c|c|c|}
\hline Kodlar & f & $\%$ & Örnek Cümle \\
\hline Sayı ve nitelik azaldı & 10 & $45,45 \%$ & $\begin{array}{l}\text { Ders içinde yer vereceğimiz etkinliklerin } \\
\text { genel olarak yetersiz olduğunu } \\
\text { düşünüyorum. (Ö7) } \\
\text { Kitaplarımızdaki etkinliklerin bazıları } \\
\text { ögrencilerimizi sıkıyor,daha az nitelikli. } \\
\text { Bazen de bir konuya çok az yer verilmiş } \\
\text { oluyor. Sayıca yetersiz(Ö17) Etkinliklerin } \\
\text { azaldığını gözlemledim. Yeterli etkinlik } \\
\text { verilmiyor.(Ö1) }\end{array}$ \\
\hline Değişmedi & 8 & $36,36 \%$ & $\begin{array}{l}\text { Değişiklik olmadı.(Ö3) } \\
\text { Çok bir farklılık oluşmadı(Ö12) }\end{array}$ \\
\hline Kaldırıldıktan sonra nitelik ve çeşit arttı & 4 & $18,18 \%$ & $\begin{array}{l}\text { Daha nitelikli etkinliklere yer veriyorum. } \\
\text { Sayı aslında pek azalmadı. } \\
\text { Konunun özelliğine göre etkinlik arttı.(Ö2) } \\
\text { Ögretmenlerin kendi özgün fikirlerinden } \\
\text { hareketle etkinliklerini artırdı̆̆ını ve } \\
\text { haliyle bu etkinliklerin daha kaliteli bir hal } \\
\text { aldığ kanaatindeyim. (Ö5) }\end{array}$ \\
\hline Toplam & 22 & $100,00 \%$ & \\
\hline
\end{tabular}

Tablo 9 incelendiğinde görüşme yapılan öğretmenlerden 10’u kılavuz kitapların kaldırılmasından sonra ders kitaplarında yer alan etkinliklerin sayısının ve niteliğinin azaldığı yönünde görüş belirtmiştir. Bu görüşte olan öğretmenler genel olarak etkinliklerin kazanımların öğrencilere kazandırılmasında hafif kaldığını ifade etmişlerdir. Görüşme yapılan 8 öğretmen ise etkinliklerin içerik ve sayısı konusunda herhangi bir değişimin olmadığını belirtmiştir. 4 öğretmen ise kılavuz kitapların kaldırılmasından sonra ders içinde yaptıkları etkinliklerin sayısının ve niteliğinin arttığını belirtmiştir.

Çalışmanın 7. alt amacı olan öğretmen kılavuz kitaplarının kaldırılmasının öğrencilerin öğrenme süreci açısından etkileri ile ilgili öğretmen görüşleri Tablo 10'da verilmiştir. 
Tablo 10. Öğretmen kılavuz kitaplarının kaldırılmasının öğrencilerin öğrenme süreci açısından etkileri ile ilgili öğretmen görüşleri

\begin{tabular}{|c|c|c|c|}
\hline Kodlar & f & $\%$ & Örnek Cümle \\
\hline Etkilemedi & 17 & $77,27 \%$ & $\begin{array}{l}\text { Bu konuda bir etkisinin olduğunu } \\
\text { düşünmüyorum.(Ö15) } \\
\text { Öğrenci açısından değişen bir şey yok... } \\
\text { (Ö10) }\end{array}$ \\
\hline Kısmen etkiledi & 5 & $22,73 \%$ & $\begin{array}{l}\text { Zaman yönetimindeki sıkıntı öğrenme } \\
\text { sürecine de yansımıştır.(Ö4) } \\
\text { Kılavuz kitaplar öğretmenin işini } \\
\text { kolaylaştırıyordu. Haliyle ögretmen daha rahat } \\
\text { ders işliyordu. Bu da ögrencilerin öğrenme } \\
\text { ortamına olumlu katka yapıyordu.(Ö19) } \\
\text { Kılavuz kitapta daha fazla etkinlik ve soru } \\
\text { vardı. Temalarda tavsiye edilecek kitap } \\
\text { isimleri vardı. Öğrencilerimizin ögrrenme } \\
\text { alanları bu açıdan darlmış olabilir. (Ö17) }\end{array}$ \\
\hline Toplam & 22 & $100,00 \%$ & \\
\hline
\end{tabular}

Tablo 10 incelendiğinde görüşme yapılan 17 öğretmen kılavuz kitapların kaldırılmasının öğrencilerin öğrenme süreci üzerinde herhangi bir etkisinin olmadığı yönünde görüş belirtirken 5’i ise bu durumun süreci kısmen etkilediğini belirtmiştir. Kısmen etkilediği görüşünde olan öğretmenler planlama, materyal ve öğretmene güven konusu üzerinde durmuştur.

Ayrıca araştırmaya katılan öğretmenlere sorulan “Öğretmen kılavuz kitapların kaldırılması ile ilgili söylemek istediğiniz başka bir şey var mı?” sorusuna verdikleri cevaplara ilişkin veriler Tablo 11'de verilmiştir.

Tablo 11. Öğretmen kılavuz kitaplarının kaldırılması ile ilgili öğretmenlerin ek görüşleri

\begin{tabular}{|c|c|c|c|}
\hline Kodlar & f & $\%$ & Örnek Cümle \\
\hline Yeniden kullanılmalı & 11 & $50,00 \%$ & 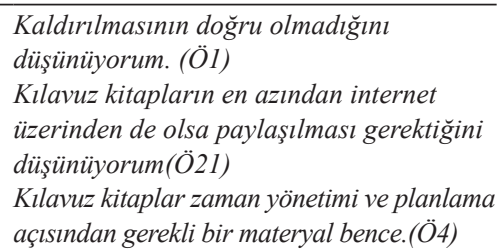 \\
\hline Kaldırılması fark yaratmadı & 9 & $40,91 \%$ & $\begin{array}{l}\text { Bizler açısından çok bir şeyin } \\
\text { değişmediğini söyleyebilirim. (Ö3) } \\
\text { Derslerin işlenişine çok büyük bir etkisi } \\
\text { yoktu. Eksikliğini hissetmiyorum.(Ö12) }\end{array}$ \\
\hline Kaldırılması iyi oldu & 2 & $9,09 \%$ & $\begin{array}{l}\text { Kaldırılması isabet oldu.bununla beraber } \\
\text { ders kitaplarının niteliği de artırılırsa } \\
\text { daha iyi olur.(Ö2) } \\
\text { Kılavuz kitap öğretmeni sınırlandırıyor } \\
\text { ve yaratıcılığının önüne geçiyordu. } \\
\text { Kaldırllması yerinde bir karar.(Ö5) }\end{array}$ \\
\hline Toplam & 22 & $100,00 \%$ & \\
\hline
\end{tabular}


Tablo 11 incelendiğinde araştırmaya katılan öğretmenlerin yarısı kılavuz kitapların yeniden kullanılması gerektiği yönünde görüş belirtmiştir. Bu öğretmenlerin görüşlerine gerekçe olarak en çok vurguladıkları nokta kılavuz kitapların zaman tasarrufu ve planlama konularında öğretmenlere kolaylık sağlamasıdır. Araştırmaya katılan öğretmenlerin 9'u ise kılavuz kitapların kaldırılmasının herhangi bir fark yaratmadığ 1 yönünde görüş belirtmiştir. 2 öğretmen ise kılavuz kitapların kaldırılmasının yerinde bir karar olduğunu belirtmiştir.

\section{Sonuç, Tartışma ve Öneriler}

1- Öğretmen kılavuz kitaplarının kaldırılmasının Türkçe dersini planlama açısından nasıl etkilediği ile ilgili ögretmen görüşlerine dair sonuçlar

Görüşme yapılan öğretmenlerden 10’u kılavuz kitapların kaldırılmasının Türkçe dersini planlama açısından herhangi bir etkisinin olmadığını belirtirken 12 öğretmen ise çeşitli açılardan planlama üzerinde etkisi olduğunu söylemiştir. Etkilerin konu başlıkları frekans değerlerine göre şu şekilde sıralanmaktadır: "Zaman kaybı", "Uygulamada birliğin bozulması", "Sınıf düzeyine göre farklı plan hazırlama", "Takipte zorluk".

Kılıç (2009) tarafından yapılan çalışmada öğretmenlerin sınıf içinde, ders öncesi hazırlık ve planlama çalışmalarında, ders kitabını doğru ve verimli kullanabilmeleri için kılavuz kitapların gerekli olduğu vurgulanmıştır. ${ }^{11}$ Kılıç (2009) tarafından vurgulanan bu gereklilik ile bu araştırmanın bulguları örtüşmektedir. Nitekim araştırmaya katılan öğretmenlerin çoğu kılavuz kitapların kaldırılmasının kendilerini planlama açısından etkilediği yönünde görüş belirtmişlerdir.

2- Öğretmen kılavuz kitaplarının kaldırılmasının Türkçe dersini zaman yönetimi açısından nasıl etkilediği ile ilgili öğretmen görüşlerine dair sonuçlar

Araştırmaya katılan öğretmenlerin \%50’si öğretmen kılavuz kitaplarının kaldırılmasının Türkçe dersini zaman yönetimi açısından olumsuz etkilediğini belirtirken \%50'si hissedilen bir etkinin oluşmadığı yönünde görüş belirtmiştir. Olumsuz etkilediğini düşünen öğretmenler kılavuz kitaplar kaldırıldıktan sonra ders öncesinde planlamaya fazla zaman ayırdıklarını, ders sırasında ise konunun belirlenen sürede tamamlanması hususunda sıkıntı yaşadıklarını belirtmişlerdir.

Göçer ve Aktürk (2015) tarafından yapılan ve kılavuz kitaplar ile ilgili öğretmenlerin metaforik algılarının araştırıldığı çalışmada öğretmenler kılavuz kitapları "rehber” olarak algıladıklarını çünkü kılavuz kitapların neyi, nerede, ne zaman yapmaları gerektiği konusunda öncülük ettiğini belirtmişlerdir. ${ }^{12}$

3- Öğretmen kılavuz kitaplarının kaldırılmasının Türkçe dersini işleniş yönünden nasıl etkilediği ile ilgili öğretmen görüşlerine dair sonuçlar

11 Kılıç, “İlköğretim Birinci Kademe Derslerinde Öğretmen Kılavuzuna Duyulan İhtiyaç ve İçeriği”295-309.

12 Göçer ve Aktürk. "İlk ve ortaokul öğretmenlerinin öğretmen kılavuz kitabına yönelik algıları: Metafor analizi”,194. 
Araştırmaya katılan öğretmenlerin tamamı kendilerine yöneltilen bu soruya olumlu cevap verdikleri görülmüştür. Öğretmenlerin \%36,36’sı kılavuz kitapların derste planlı olmalarını sağladığını belirtirken, \%22,73'ü kitapların yöntem ve teknik bakımından yol gösterici olduğunu söylemiştir. \%18'i ise kılavuz kitapların derste kendilerine zaman tasarrufu sağladığını söylemişlerdir. Diğer katılımcılar da derste "Başvuru kaynağı" $(\% 13,64)$ ve "Etkinlik açısından doyurucu kaynak" (\%9) olduğunu belirtmişlerdir. Bu sonuçlardan hareketle kılavuz kitapların Türkçe dersi işlenişini olumlu yönde etkilediği sonucuna ulaşılabilir.

Göçer (2011) tarafından ilköğretim 2. Kademe Türkçe dersi öğretmen kılavuz kitaplarının işlevini belirlemek amacıyla 12 katılımcı öğretmenle yapılan çalışmada öğretmen kılavuz kitaplarının araştırmaya katılan öğretmenlerin çoğu tarafından ders işleme sürecinin bir bölümünde kullanıldığg belirtilmiştir. ${ }^{13} \mathrm{Bu}$ sonuç ile yaptığımız araştırmadan çıkan sonuç kılavuz kitapların öğretmenler tarafından derste yöntem, plan, bilgi, etkinlik gibi bakımlardan bir başvuru kaynağı olarak kullanıldığı ortaya çıkmaktadır.

4- Öğretmen kılavuz kitaplarının kaldırılmasının ögretmenlerin meslekî becerisi ve yaratıcılı̆̆ına etkisi ile ilgili ögretmen görüşlerine dair sonuçlar

Araştırmaya katılan öğretmenlerin \% 36,36'sı (8) öğretmen kılavuz kitaplarının kaldırılmasının öğretmenin yaratıcılığını artırdığını belirtmiştir. Öğretmenlerin \% 31,82'si (7) ise kılavuz kitapların öğretmenlerin meslekî becerilerine ve yaratıcılıklarına herhangi bir etkisinin olmadığını söylemiştir. Öğretmenlerin \%27,27'si (6) ise kılavuz kitapların özellikle göreve yeni başlayan öğretmenlere meslekî beceri ve yaratıcılık bakımından yararlı olduğunu belirtmişlerdir. Bu bulgulardan hareketle öğretmenlerin yaklaşık \% 70'i, kılavuz kitapların öğretmene meslekî beceri ve yaratıcılık konularında herhangi bir katkısının olmadığını düşünmektedir. Geri kalan \%30'luk kesim ise kılavuz kitapların özellikle mesleğe yeni başlayan öğretmenlerin meslekî becerilerine katkı sağlayacağı görüşündedir

İlik (2011) tarafından hazırlanan ve 8. Sınıf Türkçe dersi öğretmen kılavuz kitaplarının yapılandırmacı öğrenme anlayışına göre değerlendirildiği çalışmada değerlendirme ölçütlerinden biri olan "Ders öğretmenine öğrenme ve değerlendirme etkinliklerinde seçme ve değiştirme olanağ1 vermesi” ölçütünün frekansı en az olan ölçüt olduğu sonucuna ulaşılmıştır. ${ }^{14}$

Öğretmen kılavuz kitabında öğretmenlere daha çok etkinlik üretme ya da seçme şansı verecek, esnek bir yapının olmadığı ve benzer etkinliklerin aynı şekilde sıralanmasının öğretmenlerin üretkenliğini etkileyeceği belirtilmiştir.

Göçer (2011) tarafından yapılan çalışmanın sonucuna göre ise öğretmenler, kılavuz kitapta olanları harfiyen uygulamaktan öte gidememekte, özgün etkinlikler yerine verilen çalışmayı temel hedefmiş gibi uygulamaktadırlar. Bu ise öğretmenleri uygulamalarında monotonluğa itmekte ve süreçte yaratıcılıklarını köreltmektedir. Yine aynı çalışmanın öneriler kısmında kılavuz kitapların mesleğe yeni başlayan öğretmenlere verilmesi tavsiye edilmektedir. ${ }^{15}$

13 Göçer,“İlköğretim İkinci Kademe Türkçe Öğretmen Kılavuz Kitaplarının İşlevselliğinin Belirlenmesi”,162.

14 İlik, "İlköğretim 8. Sinıf Türkçe Dersi Öğretmen Kılavuz Kitabının Yapılandırmacı Öğrenme Anlayışına Göre Incelenmesi", 62.

15 Göçer,“illköğretim İkinci Kademe Türkçe Öğretmen Kılavuz Kitaplarının İşlevselliğinin Belirlenmesi”,163. 
İki araştırmanın sonucu ile bu araştırmanın sonucunun örtüştüğü görülmektedir.

5- Kılavuz kitaplar kaldırıldıktan sonra basılan ders kitaplarının içerik ve yeterliliğ $i$ hakkındaki öğretmen görüşlerine dair sonuçlar

Araştırmaya katılan öğretmenlerin \% 40,91'i ders kitaplarını içerik ve yeterlilik bakımından yetersiz bulmaktadır. \%18,18'i ders kitaplarında herhangi bir değişikliğin olmadığını düşünürken, \%18,18'i de kitapların içeriğinin sadeleştiğini düşünmektedir. \%13,64 'ü ise ders kitaplarında yer alan metinlerin sınıf seviyelerine uygun olmadığını belirtmiştir. Araştırmaya katılan öğretmenlerden sadece \%9'u ders kitaplarını yeterli bulduklarını belirtmişlerdir. Buradan hareketle kılavuz kitapların kaldırılmasından sonra kullanılan ders kitapları hakkında öğretmenlerde olumsuz bir görüş hâkimdir. Metinlerin sınıf seviyelerine uygunluğu, metinlerde yer alan etkinlikler, metinlerin işlenme süresi gibi konular öğretmenlerin bu bağlamda dile getirdiği hususlardır.

Öztürk ve Çerçi tarafından hazırlanan ölçek ${ }^{16}$ kullanılarak Öztürk (2019) tarafından hazırlanan ve Türkçe öğretmenlerinin ders kitaplarına bağlılık durumlarının araştırıldığg çalışmada Türkçe öğretmenlerinin ders kitaplarına bağlılık oranının \%59,815 olduğu belirtilmiştir. ${ }^{17}$ Buradan da hareketle dersin en önemli materyallerinden biri olan ve öğretmenlerin çoğu tarafından da bağlı kalınan ders kitaplarının içerik ve yeterliliği konusu özellikle kılavuz kitaplar kaldırıldıktan sonra üzerinde durulması gereken bir nokta olarak ön plana çıkmaktadır.

6- Öğretmen kılavuz kitaplarının kaldırılmasından sonra ders içi etkinliklerin sayısı ve niteliğine yönelik ögretmen görüşlerine dair sonuçlar

Araştırmaya katılan öğretmenlerin \% 45,45'i kılavuz kitaplar kaldırıldıktan sonra ders içi etkinliklerin sayısının azaldığını, niteliğinin düştüğünü belirtirken \%36,36'sı herhangi bir değişikliğin olmadığı görüşündedir. \% 18'i ise kılavuz kitaplar kaldırıldıktan sonra ders içi etkinliklerin niteliğinin ve sayısının arttığını düşünmektedir. Buradan hareketle kılavuz kitapların kaldırılmasının ders içi etkinliklerin sayısını ve niteliğini genel olarak olumsuz yönde etkilediği sonucuna varılabilir.

7-Öğretmen kılavuz kitaplarının kaldırılmasının ögrencilerin öğrenme süreci açısından etkileri ile ilgili öğretmen görüşlerine dair sonuçlar

Araştırmaya katılan öğretmenlerin \%77,27'si kılavuz kitapların kaldırılmasının öğrencilerin öğrenme süreçlerine herhangi bir etkisinin olmadığını belirtmiştir. \%22'si ise bu durumun öğrenme sürecini kısmen etkilediği görüşündedir. Bu görüşte olanların etki eden faktör olarak üzerinde durdukları hususlar zaman yönetimi ve etkinlik sayısıdır. Buradan hareketle öğretmen kılavuz kitaplarının kaldırılması öğrencilerin öğrenme süreçlerini büyük oranda etkilemediği sonucuna ulaşıllabilir.

Öğretmen kılavuz kitaplarının kaldırılması ile ilgili ögrretmenlerin ek görüşlerine dair sonuçlar

16 Öztürk ve Çerçi. “Türkçe Öğretmenlerinin Ders Kitaplarına Bağllılıları Ölçeği’nin Geliştirilmesi: Geçerlilik ve Güvenilirlik Çalışması",876-897.

17 Öztürk "Türkçe Öğretmenlerinin Ders Kitaplarına Bağlılık durumları",46. 
Araştırmaya katılan öğretmenlerin \%50'si kılavuz kitapların yeniden kullanılması yönünde görüş belirtirken \% 9’u kaldırılmasının iyi olduğu yönünde görüş belirtmiştir. Geri kalan kısım ise kaldırılmasının bir fark yaratmadığı görüşündedir. Buradan hareketle öğretmenlerin çoğunun kılavuz kitapların kaldırılmasını olumlu bulmadığı sonucuna ulaşılabilir.

\section{Öneriler}

Araştırmaya katılan öğretmenlerin çoğu kılavuz kitapların yeniden kullanılmasının iyi olacağ1 yönünde görüş belirtmiştir. Özellikle mesleğe yeni başlayan öğretmenler için kılavuz kitapların deneyim kazanmaları adına faydalı olacağı düşünülmektedir.

Kılavuz kitapların kaldırılmasından sonra kullanılan ders kitaplarının içerik ve nitelik bakımından yeterlilikleri önem arz etmektedir.

Kılavuz kitapların kaldırılmasından sonra öğretmenlerin sıkıntı çektiklerini belirttikleri ders planlama, zaman yönetimi gibi konularda öğretmenlere yol gösterecek çalışmaların bakanlığa bağlı dijital ortamlarda öğretmenlerle paylaşılması faydalı olabilir.

Hakem Değerlendirmesi: Dış bağımsız.

Çıkar Çatışması: Yazarlar çıkar çatışması bildirmemiştir.

Finansal Destek: Yazarlar bu çalışma için finansal destek almadığını beyan etmiştir.

Peer-review: Externally peer-reviewed.

Conflict of Interest: The authors have no conflict of interest to declare.

Grant Support: The authors declared that this study has received no financial support.

\section{Kaynaklar/References}

Alkış Küçükaydın, Menşure, Ademİşcan. "İlköğretim 3. Sınıf Türkçe Ders Kitapları ve Öğretmen Kılavuz Kitabının Yapılandırmacı Öğrenme Yaklaşımına Uygunluk Düzeyi.” Ana Dili Eğitimi Dergisi 5.1 (2017): 1-13.

Ayvacı, Hakan Şevki ve Sibel Er-Nas, “ "Öğretmen Kılavuz Kitaplarının Yapılandırmacı Kurama Göre Öğretmen Görüşlerine Dayalı Olarak Değerlendirilmesi”, Necatibey Eğitim Fakültesi Elektronik Fen ve Matematik Eğitim Dergisi, Cilt 3, Say1 2 (2009). 212-225.

Ayvacı, Hakan Şevki, Tülay Şenel Çoruhlu. «Illköğretim 7. Sınıf Fen Ve Teknoloji Öğretmen Kılavuz Kitabının Öğretmen Görüşlerine Dayalı Olarak Değerlendirilmesi.» Erzincan Üniversitesi Eğitim Fakültesi Dergisi 13.1 (2011): 24-38.

Büyüköztürk, Şener, Ebru Kılıç Çakmak, Özcan Erkan Akgün, Şirin Karadeniz ve Funda Demirel, Bilimsel Araştırma Yöntemleri (27.basım). Ankara: Pegem Akademi, 2019.

Durukan, Erhan. Türkçe Dersi Öğretim Programının (6-8. Sinıflar) Hedef ve Kazanımları Doğrultusunda 7. Sinıf Türkçe Dersi Öğrenci Çalışma ve Öğretmen Kılavuz Kitaplarının Değerlendirilmesi, Yüksek lisans tezi, Karadeniz Teknik Üniversitesi, 2008. 
Erdoğan, Tolga. "İlköğretim 3. Sınıf Türkçe Dersi Öğretmen Kılavuz Kitabı Ve Öğrenci Çalışma Kitabının Yapılandırmacı Yaklaşıma Uygunluğu.” Mehmet Akif Ersoy Üniversitesi Eğitim Fakültesi Dergisi 8.14 (2007): 163-172.

Göçer, Ali. “İlköğretim İkinci Kademe Türkçe Öğretmen Kılavuz Kitaplarının İ̧̧levselliğinin Belirlenmesi”, Journal of International SocialResearch, 4/16, (2011): 154-164.

Göçer, Ali ve Yunus Aktürk. "İlk ve ortaokul öğretmenlerinin öğretmen kılavuz kitabına yönelik algıları: Metafor analizi”, Uluslararası Türk Eğitim Bilimleri Dergisi, (4), (2015): 186-199.

Güneş, Firdevs. Türkçe Öğretimi Yaklaşımlar ve Modeller. Ankara: Pegem Akademi, 2020.

İlik, Mustafa. İlköğretim 8. Sinıf Türkçe Dersi Öğretmen Kılavuz Kitabının Yapılandırmacı Öğrenme Anlayışına Göre İncelenmesi. Yüksek Lisans tezi, Frrat Üniversitesi Sosyal Bilimler Enstitüsü, 2011.

Kılıç, Abdurrahman. "İlköğretim Birinci Kademe Derslerinde Öğretmen Kılavuzuna Duyulan İhtiyaç ve İçeriği”, Selçuk Üniversitesi Sosyal Bilimler Enstitüsü Dergisi, 21 (2009), 295-309.

Kulantaş, Nazike. 4. ve 5. Sinıf Sosyal Bilgiler Dersinde Kullanılan Ders ve Öğrenci Çalışma Kitapları ile Öğretmen Kılavuz Kitaplarının Öğretmen, Öğrenci ve Veli görüşlerine Göre Değerlendirilmesi. Doktora tezi, Gazi Üniversitesi Eğitim Bilimleri Enstitüsü, 2007.

Matthew B. Miles ve A. Michael Huberman, Genişletilmiş bir kaynak kitap: Nitel veri analizi(3.Baskı).Ankara: Pegem Akademi,2019.

MEB Talim ve Terbiye Kurulu Başkanlığı. İlköğretim Türkçe Dersi Öğretim Programı ve Kılavuzu (1-5. sinuflar). Ankara: MEB Basımevi, 2005.

MEB.Talim ve Terbiye Kurulu Başkanlığı İlköğretim Türkçe Dersi(6,7,8. Sınıflar) Öğretim Programı ve: MEB Basımevi. (2006).

"Millî Ĕgitim Bakanlı̆̆ Ders Kitapları ve Eğitim Araçları Yönetmeliğg”" Resmi Gazete, 12 Eylül 2012 Sayl:28409 Erişim:18 Aralık 2019 www.resmigazete.gov.tr

Öztürk, Ahmet Tayfun ve Arif Çerçi. “Türkçe Öğretmenlerinin Ders Kitaplarına Bağlılıkları Ölçeği’nin Geliştirilmesi: Geçerlilik ve Güvenilirlik Çalışması”, Ana Dili Eğitimi Dergisi, 7 /4 (2019), 876-897. Erişim 9 Ağustos 2020, DOI: 10.16916/aded.578034

Öztürk, Ahmet Tayfun. "Türkçe Öğretmenlerinin Ders Kitaplarına Bă̆llllk durumları" Yüksek Lisans Tezi, Gaziantep Üniversitesi Eğitim Bilimleri Enstitüsü, 2019.

Sert, Fethiye. İlköğretim 7. Sinıf Türkçe Dersi Öğretmen Kılavuz Kitabının Yapılandırmacı Öğrenme Anlayışına Göre İncelenmesi. Yüksek Lisans tezi, Frrat Üniversitesi, 2012.

Şahin, Ayfer. «İlköğretim Birinci Sınıf Türkçe Ders Kitabı, Öğrenci Çalışma Kitabı Ve Öğretmen Kılavuz Kitabının Öğretmen Görüşlerine Dayalı Olarak Değerlendirilmesi.» Ahi Evran Üniversitesi Kırşehir Eğitim Fakültesi Dergisi 9.3 (2008): 133-146.

Şeker, Mustafa. "Sosyal Bilgiler Ders, Çalışma ve Öğretmen Kılavuz Kitaplarının Öğrenme Stilleri Açısından İncelenmesi”.Kastamonu Ĕgitim Dergisi 22 (2014) :41-56.

Yaylı, Derya, Murat Solak. “Ortaokul Türkçe Ders Kitaplarında ve Öğretmen Kılavuz Kitaplarında Yer Alan Yazma Etkinliklerine Dair Öğretmen Görüşleri”. Electronic TurkishStudies, 9(6) (2014): 1139-1151.

Yıldırım, Ali ve Hasan Şimşek. Sosyal Bilimlerde Nitel Araştırma Yöntemleri (5. Baskı). Ankara: Seçkin Yayınc1lı, 2005.

Özden, Yüksel. Öğrenme ve Öğretme. Ankara: Pegem Akademi, 2021. 
